\title{
Kirjoitettu kevät 1918
}

\author{
McKeough, Andreas. 2017. Kirjoittaen kerrottu sota: Tutkimus vuoden 1918 \\ sodan kerronnallisesta käsittelystä omaelämäkerrallisissa teksteissä. Helsinki: \\ Työväen historian ja perinteen tutkimuksen seura. 344 sivua.
}

\section{Merja Leppälahti}

\begin{abstract}
A ndreas McKeough tarkastelee väitöskirjassaan Kirjoittaen kerrottu sota vuoden 1918 sodan kokemista omaelämäkerrallisissa teksteissä. Tutkijan lähestymistapa on konstruktiivinen: hän tulkitsee kertojien omia, subjektiivisia tulkintoja siitä, miten erilaisista taustoista lähtöisin olevat henkilöt kokivat sodan. Tutkimus paikantuu kulttuurintutkimuksen kentällä muistitietotutkimuksen, omaelämäkerrallisen kerronnan tutkimuksen ja folkloristiikan alueille. McKeough tuo vertailevan näkökulman punaisen ja valkoisen muistitiedon tutkimukseen. Analyysissaan hän nostaa esille kokemusten esittämiseen ja tulkintaan liittyviä ideologisia ja kulttuurisia tekijöitä ja tuo näkyviin yksilöllisten tulkintojen moninaisuuden.
\end{abstract}

\section{Tutkimuksen aineisto}

Muistitietoaineistoihin kuuluvat muistinvaraiset kirjalliset aineistot, kuten omaelämäkerralliset tekstit ja kilpakeruuvastaukset. Tutkimuksen keskeisenä aineistona ovat kahdentoista henkilön tekstit. Aineistokirjoitusten joukossa on neljä päiväkirjaa vuodelta 1918, ja osa muistelmistakin pohjautuu päiväkirjoihin. Kirjoittajissa on sekä valkoisia että punaisia, miehiä ja naisia. Kirjoittajat olivat vuonna 1918 iältään neljästätoista 57-vuotiaaseen. Tekstit on kirjoitettu vuosina 1918-1935, ja ne ovat peräisin useasta eri arkistosta. Aineisto on siis kirjoittajien lukumäärästä huolimatta mahdollisimman kattava, mikä sopii tutkimuksen kysymyksenasetteluun.

Elämäntarinoissa kertojat kuvaavat omaa elämäänsä käyttäen kertomuksia, jotka ovat kerrontahetkellä kertojalle erityisen keskeisiä ja merkityksellisiä. Aineiston yhtenä valintakriteerinä on ollut kirjoitusten henkilökohtainen ote, jolla tutkija tarkoittaa tekstien sisältämää kokemusten, kokemisen tapojen, toiminnan, tunteiden ja mielipiteiden kuvausta. McKeough oivaltaa ja sanallistaa hyvin myös sen, että aineistotekstien valintaan vaikuttavat myös tutkijan intuitiiviset ja emotionaaliset tekijät. Yksi teksti herättää mielenkiintoa ja puhuttelee, joku toinen teksti jättää kylmäksi.

Vuoden 1918 tapahtumia käsitteleviin aineistoihin liittyy paljon sellaista, mitä voisi pitää arkaluontoisena tietona. Esimerkiksi kertojien uskonnollinen ja poliittinen vakaumus on 
tutkimuksen kannalta aivan oleellinen seikka. McKeough käsittelee kuitenkin aineistonsa kirjoittajia näiden omilla nimillä pyrkimättä salaamaan näiden henkilöllisyyttä. Hän perustelee toimintansa huolellisesti. Ensinnäkin kaikki tekstit on kirjoitettu yli 75 vuotta sitten, osa lähes sata vuotta sitten, ja ne on luovutettu julkisiin arkistoihin. Muistelmatekstit on jo tekstityyppinä suunnattu ulkopuoliselle lukijalle. Yksi kirjoittaja on häivyttänyt henkilöllisyytensä käyttämällä nimimerkkiä, ja muutkin olisivat voineet sen halutessaan tehdä. Osa teksteistä on myös julkaistu aikaisemmin. Lisäksi erityisesti heikossa yhteiskunnallisessa asemassa olleiden ihmisten kokemusten ja toimijuuden nostamista esille pidetään nykyään jo itsessään tärkeänä.

\section{Henkilökohtainen kokemus, maailmankuva ja kulttuurinen tieto}

McKeough jakaa tutkimuksessaan yksilön omaaman tiedon toisaalta subjektiivisesti määrittyneeseen kokemukselliseen tietoon ja toisaalta kulttuuriseen ja merkityksiltään kiteytyneeseen jaettuun tietoon. Kokemuksellinen tieto rakentuu henkilön oman elämänhistorian ja episodisen muistin pohjalta. Tapahtumien tulkintaan ja kuvaamiseen vaikuttaa kuitenkin myös kokijan oma maailmankuva ja maailmankatsomus.

Omaelämäkerralliselle kertomukselle on tyypillistä, että kertomukseen valitaan toisaalta yleisesti mielenkiintoisilta tuntuvia kokemuksia ja toisaalta hyvin arkisiakin tapahtumia, jos niissä on yksilölle jotain erityisen merkityksellistä. Omaelämäkerrallisen kerronnan luonteeseen kuuluu myös emotionaalisuus eli affektiivinen, tunteisiin vetoava funktio. Eletyn todellisuuden kuvaamiseen yhdistyy tunnepitoisia ja arvopohjaisia piirteitä.

Yksilölliset maailmankuvat ja maailmankatsomukset pohjautuvat pitkälti erilaisille sosiaalisille ryhmille ominaisiin uskomuksiin, ideoihin ja selitystapoihin, toisin sanoen jaettuun, kulttuuriseen tietoon. McKeough on lisännyt kirjan loppuun liitteen, jossa hän vielä uudelleen kuvailee tutkimuksen keskeiset käsitteet. Tämä on tarpeen, sillä monet humanististen tieteiden käyttämistä käsitteistä ovat monitulkintaisia ja niitä käytetään eri tutkimuksissa eri tavoin. Kulttuurisen tiedon McKeough määrittelee liitteessä 1 seuraavasti:

Kulttuurinen tieto on kollektiivista ja sosiaalista tietoa, tietyn kulttuurin jäsenien jakamaa tietoa maailmasta. Se muodostuu ja välittyy sosiaalisessa interaktiossa ja merkitysten muodostamisen yksilöllisissä ja kollektiivisissa prosesseissa. Kulttuurinen, jaettu tieto, joka kohdistuu historiaan elettynä, koettuna ja tulkittuna menneisyytenä, rakentuu kollektiivisen muistamisen prosesseissa.

McKeough nostaa esille myös avainkokemukset eli sellaiset kertojalle merkittävät kokemukset, jotka näyttävät vaikuttavan myös muiden kokemusten tulkintaan. Vaikeita avainkokemuksia ovat esimerkiksi vankileiriaika, läheisten kuolema, joukkoteloituksen todistaminen tai punaisten kertomusten kuvaus sodan häviämisestä. Kiinnostavasti näyttää myös siltä, että valkoisella puolella kirjoituksissa nostetaan esille yksilöllisen muistitiedon tallentamisen tärkeyttä, kun taas punaisiin identifioituvat kirjoittajat korostavat tapahtumien kollektiivista muistamista.

Tutkimuksessa nostetaan esille myös muita kertomiseen vaikuttavia seikkoja. Esimerkiksi se, kenelle kerronta on suunnattu, vaikuttaa sekä kertomuksen sisältöön että muotoon. 


\section{Moninaiset tulkinnat}

McKeough on tarkastellut väitöskirjassaan vuoden 1918 tapahtumiin liittyvien kokemusten kerronnallista käsittelyä kirjallisissa aineistoissa. Tutkimuksen kohteena ovat sekä kokemukset kertomuksissa että kertomusten kulttuuriset piirteet. Hän näkee kerronnassa keskeisenä kaksi prosessia, jotka ovat toisaalta subjektiivinen muistelu, muistaminen ja kirjoittaminen, toisaalta narratiivisen toimijuuden konstruointi. Nämä prosessit kietoutuvat yhteen, ja molempia määrittävät yksilölliset, kulttuuriset ja yhteiskunnalliset kontekstit.

Vuoden 1918 tapahtumilla on monta nimeä: kapina, sisällissota, veljessota, vapaussota. Vapaussota-nimitystä korostettiin sodan jälkeen julkisissa yhteyksissä. Esimerkiksi vuonna 1933 vietettiin näyttävästi vapaussodan päättymisen 15-vuotisjuhlaa. Vaikka punaisen puolen vastakertomuksia kirjoitettiin ja julkaistiinkin jonkun verran, ne eivät saavuttaneet laajoja lukijakuntia. McKeough toteaakin, että arkistoissa olevien tekstien kirjoittamisaika on vaikuttanut vahvasti siihen, miten sodan kokemuksia teksteissä käsitellään. Arkistoaineistojen valkoisten kertojien tekstit on usein kirjoitettu heti tai melko pian sodan jälkeen, kun taas punaisia kannattaneiden kertomuksia on eniten 1960-luvulta, jolloin punaisten näkökulmia oli jo helpompi tuoda esille. McKeough on kuitenkin onnistuneesti valinnut aineistoonsa molemmilla osapuolilta tekstejä, joita voi sanoa aikalaisaineistoiksi. Silti hänenkin aineistoissaan päiväkirjojen ja hiukan myöhemmin kirjoitettujen muistelmatekstien kerronnassa on eroja.

McKeough toteaa varsin odotetusti, että kirjoittajan maailmankatsomus ja ideologinen tausta vaikuttavat omien kokemusten ja sodan tulkintoihin. Hän osoittaa, että vuoden 1918 sodan kokemisen tavat ovat hänen aineistossaan osittain ainutkertaisia, osittain yhteneviä. Valkoisten ja punaisten kertojien tekstien välillä on kuitenkin selvä rajalinja, ja yksilötason tulkinnat sodasta eroavat täysin rajalinjojen eri puolilla.

Vuoden 1918 sodasta on kulunut sata vuotta eikä tuon ajan tapahtumia omakohtaisesti muistavia ole enää elossa. Sodanaikaiset kohtalot ja tapahtumat ovat kuitenkin monissa suvuissa säilyneet sukumuistoina nykypäivään saakka tai niistä ei ole puhuttu lainkaan. Kiinnostus aiheeseen on joka tapauksessa lisääntynyt. Vaikka vuoden 1918 sotaa on tutkittu paljon, Kirjoittaen kerrottu sota on tervetullut lisä vuoden 1918 sodan kokeneiden kirjallisten esitysten kuvaamiin yksilöllisiin tulkintoihin ja kokemusmaailmoihin.

Filosofian lisensiaatti Merja Leppälahti on tietokirjailija ja kirjallisuuskriitikko sekä folkloristiikan tohtorikoulutettava Turun yliopistossa. 